\begin{tabular}{r|l} 
artículos & LITERARY NARRATIVE IN \\
& THE DAILY PRIN'T MEDIA: \\
& Zero Hora and Gazeta do Sul'
\end{tabular}

Copyright (c) 2014 SBPjor / Associação Brasileira de Pesquisadores em Jornalismo

DEMÉTRIO DE AZEREDO SOSTER

Universidade de Santa Cruz do Sul

FABIANA QUATRIN PICCININ

Universidade de Santa Cruz do Sul

\begin{abstract}
This paper aims to investigate the presence of specific categories in journalistic narratives in daily newspapers - feature story and interpretative news- and their use of elements from the literary narrative. This movement presents itself as a strategy from which the devices reiterate their identity links, making possible their operations, producing new meanings and provoking differences that generate further differences. The results of the empirical research undertaken over 30 days - from September 1 st to September 30th, 2010 - based on two of the main daily newspapers in Rio Grande do Sul: Zero Hora, from Porto Alegre, and Gazeta do Sul, from Santa Cruz do Sul, suggest that a process of increasing complexity in journalism is at play, as revealed by the lack of journalistic categories and genres, hitherto viewed as indicators of deeper layers of meaning than textual reificators.
\end{abstract}

Keywords: Genres. Feature News. Interpretative journalism. Mediatized journalism. Literary narrative.

\title{
NARRATIVAS LITERÁRIAS NO JORNALISMO IMPRESSO DIÁRIO: o caso dos jornais Zero Hora e Gazeta do Sul
}

RESUMO - Este artigo investiga a presença de determinadas categorias nas narrativas jornalísticas em jornais diários - diversional e interpretativo -, e o uso por esses de elementos da narrativa literária. Um movimento que se apresenta como uma estratégia por meio da qual os dispositivos reforçam seus vínculos identitários, viabilizando suas operações, gerando novos sentidos e provocando diferenças que geram diferenças. Os resultados de pesquisa empírica realizada por 30 dias - de $1^{\circ}$ a 30 de setembro de 2010 - em dois dos principais jornais diários do Rio Grande do Sul: Zero Hora, de Porto Alegre, e Gazeta do Sul, de Santa Cruz do Sul sugerem que há uma complexificação em processo no jornalismo que se manifesta na já insuficiência das categorias e gêneros jornalísticos, observados antes como indicadores de camadas mais profundas de significação do que reificadores textuais.

Palavras-Chave: Gêneros. Jornalismo diversional. Jornalismo Interpretativo. Jornalismo midiatizado. Narrativas. 


\section{NARRATIVAS LITERARIAS EN EL PERIODISMO IMPRESO DIARIO: el caso de los periódicos Zero Hora y Gazeta do Sul}

RESUMEN - Este artículo investiga la presencia de determinadas categorías en las narrativas periodísticas en periódicos diarios - diversional e interpretativo - , y el uso por estos de elementos de la narrativa literaria. Un movimiento que se presenta como una estrategia por medio de la cual los dispositivos refuerzan sus vínculos identitarios, viabilizando sus operaciones, generando nuevos sentidos y provocando diferencias que generan diferencias. Los resultados de pesquisa empírica realizada por 30 días - de $1^{\circ}$ a 30 de septiembre de 2010 - en dos de los principales periódicos diarios del Río Grande del Sur: Zero Hora, de Porto Alegre, y Gazeta do Sul, de Santa Cruz do Sul, sugieren que hay una complejidad en proceso en el periodismo que se manifiesta ya en la insuficiencia de las categorías y géneros periodísticos, observados antes como indicadores de camadas de más profundas significaciones de que reificadores textuales.

Palabras clave: Géneros. Periodismo diversional. Periodismo interpretativo. Periodismo mediatizado. Narrativa literaria.

\section{JOURNALISM AS A COMPLEX SYSTEM}

A possible strategy to understand the current socialtechnological-discursive metamorphosis in journalism is to observe it from a systemic perspective. In other words, journalism, as a complex system, has characteristics that allow it to remain autonomous ${ }^{2}$, with its own codes, rules, deontology and operations, whose objective is its maintenance as a system, in a self-referential logic. 'Em todos os tipos de autorreferência nos encontramos diante de uma circularidade fechada, que não nega a existência do entorno: este é o pressuposto das seleções do sistema ${ }^{3}$ ' (BARALDO; CORSI; ESPOSITO, 1996, p. 36-37).

The first case, which concerns journalism's 'nature', shall not be discussed in this article. The focus lies in the analysis of narrative strategies that allow the journalistic system to be distinguished from other systems, and viable as such; they make the identification of such specificity possible, even when, in the operations, the journalistic system interferes in and undergoes interference from them or other media, in which it is inserted, in the bias of irritation ${ }^{4}$.

The most important point is not the denial of inferences between this 'nature' and the identity or role of the agents in this process, but rather the 'final product', in this case, print media, 
recognizing the difference that emerges from certain differences. In other words, it involves discussing something that, when it distinguishes, not only distinguishes, but also makes viable and identifies (LUHMANN, 2009).

Initially, (PICCININ; SOSTER, 2010), the guiding hypothesis ${ }^{5}$ was that, in a particular scenario, the phenomenon of mediatization and thus mediatization of journalism allowed the emergence of certain journalistic categories and genres ${ }^{6}$, such as feature story and interpretative news, which seemed to be relegated, mostly after digitalization, as established elements in the identity constitution of print media. Hence, they helped these devices to be established as knots and connections within the systems in which they were inserted, connecting them to other devices and making them operationally and discursively available.

As the research unfolded, attention was drawn to the presence of the two aforementioned categories in daily print media, since they are normally found in weekly magazines or books, suggesting that the identity constitution of the journalistic system is established: a) by the emergence of these categories, and b) by journalism's appropriation of literary narrative elements. Thus, journalism seeks the resources it needs, in this case from literature, so as to remain constant within the system it is inserted in, interfering and undergoing interference.

Research was continued by conducting an empirical survey during 30 days in two of the most important daily print newspapers in Rio Grande do Sul, Brazil: Zero Hora, from Porto Alegre, and Gazeta do SuP, from Santa Cruz do Sul. Results were subsequently analyzed. The survey, conducted between September 1 st and September 30th, 2010, aimed to identify texts from interpretative and feature story categories in the aforementioned newspapers. Their identification enables the study of the presence of literary narrative elements in journalism, since, compared with other genres (informative, opinionated and utilitarian, in accordance with Marques de Melo's categorization (2010)), journalistic texts are the most frequently built with such tools.

The methodology comprises three paths. First, in 'complexified narratives', the issue is contextualized. Secondly, 'Methodology strategies' discusses the tools chosen. The third, 'Data quantification', seeks to understand qualitatively the date gathered in the empirical survey, leading to the final considerations. 


\title{
2 COMPLEXIFIED NARRATIVE
}

In order to understand the current evolutional scenery ofjournalism, considering the emergence of discursive genres and the complexification caused by the approximation of distinct fields of knowledge, it is again important to note that journalism, as a social practice of sense-making, is changing. This change has technological, social-discursive and economic roots, identifiable in the scenery it is inserted.

The emergence of feature stories ${ }^{8}$ and interpretative categories in particular, can be attributed to the mediatization of journalism (PICCININ; SOSTER, 2010) ${ }^{9}$, established at the same time as the emergence of phenomena such as self-referentiality, co-referentiality and decentralization ${ }^{10}$ (SOSTER 2007, 2008, 2009, 2009-a). This has occurred thus because:

\begin{abstract}
(...) os dispositivos que representam o jornalismo estão amalgamados em rede por meio dos nós e conexões da web. Ao fazê-lo, dão forma ao sistema midiático-comunicacional ${ }^{11}$ e passam a estabelecer suas operações em fluxos informativos de natureza marcadamente auto-referencial, complexificando uma lógica evolutiva com pelo menos 300 anos de evolução ${ }^{12}$ (PICCININ; SOSTER, 2010).
\end{abstract}

On the one hand, devices such as print newspapers and magazines used to occupy a relatively isolated institutional place in the social context until recently; on the other hand, this reality has changed substantially since 1995, with the transposition of the first newspapers to the web ${ }^{13}$. The most visible aspect of this reconfiguration is the fact that, since then, not only the print media, but all devices, have been connected to the internet. Therefore, they represent knots and connections through which information flows ${ }^{14}$ take place at institutional places, demanding a specific sort of grammar.

Como fenômeno complexo, mudanças em um ou mais subsistemas alteram e condicionam a totalidade. Sendo assim, não é de se surpreender que a digitalização dos meios e modos de produção, o espírito epocal e os rearranjos políticos e econômicos demandam atualizações das questões de pesquisa e nas próprias senhas explicativas da academia ${ }^{15}$ (PRIMO, 2009, p. 7).

If devices are connected, they arguably do not occupy a central place within the system they are inserted in, and 'compete' with each other over operations (SOSTER, 2009). In this case, institutional centrality is the system itself. Therefore, it is necessary that they become not only viable, but also perfectly identifiable in the operations. Operational viability is established by virtue of the reduction of complexity (LUHMANN, 2009); 
identity is related to the use of narrative models that allow devices to be distinguished from others. This is where the use of genres that compose the interpretative and feature story categories enters the equation.

Although the debate proposed by Seixas (2009) and Chaparro (2009) regarding the genesis ${ }^{16}$ of categories and genres of journalism is important, this is not the approach adopted here. Instead, the study was conducted using instruments to identify characteristics of approximation between two fields of knowledge in the reports, drawing on the categorization proposed by Marques de Melo (2010).

Hence, interpretative journalism is understood as that which enables not only the author's stance in the text, but also a contextualized interpretation of content by whoever can access it, based on the level of happenings' newsworthiness and freedom of style. In Beltrão's words, it is a synonym for in-depth report.

With respect to feature stories, they are a narrative model attached to 'reality', which uses freedom of style to entertain rather than inform or opine (MARQUES DE MELO, 1985). In other words, in line with a recent tendency (Dicionário de Comunicação 2009), feature story journalism means literary journalism, reality literature or non-fiction literature, in-depth journalism or author journalism.

By comparing these categories, it is apparent that they: a) are free of restrictions regarding narrative structure, and b) differ in terms of topicality, which, in the case of interpretative texts, allows for contextualization of happenings ${ }^{17}$ as they happen. This topic shall not be explored in detail. Attention will be devoted to the fact that, as the categories in question emerge, there is an approximation between the fields of journalism and literature, since both draw on literary narrative resources.

This is the point at which the concept of difference that makes a difference becomes relevant. According to Luhmann (2009), the devices reproduce in the operations the general logic of the system in which they are inserted, and are then recognized as differences that make differences. It is submitted here that making a difference that makes differences is the purpose of journalism, regardless of categories or genres. Yet, there is a subtle distinction between the conventional manner and that discussed in this article. The latter concerns news characteristics.

(...) uma diferença que leva a mudar o próprio estado do sistema; tão somente pelo fato de ocorrer, transforma: lê-se que o fumo, o álcool, a manteiga, a carne congelada colocam a vida em risco, e passasse a ser (como alguém que o sabe e pode considerá-lo) outro - quer se acredite, ou não, na informação. Independentemente da forma como se decide, a comunicação fixa uma posição no 
receptor. Posteriormente, já não importa, então, a aceitação ou rejeição, nem a imediata reação à informação. O fundamental é que a informação tenha realizado uma diferença: a difference that makes a difference ${ }^{18}$ LUHMANN, 2009, p. 83).

The most significant difference is that devices seek distinction, the form and content of information using literary narrative. Many movements and reconfigurations stand out, such as the concept of author/narrator: whoever demands an interpretative response in texts that use literary narrative is the narrator rather than the author; it is the latter that brings the narrator to life.

A definição do conceito de narrador deve partir da distinção inequívoca relativamente ao conceito de autor, entidade não raro suscetível de ser confundida com aquele, mas realmente dotada de diferente estatuto ontológico e funcional. Se o autor corresponde a uma entidade real e empírica, o narrador será entendido fundamentalmente como o autor textual, entidade fictícia a quem, no cenário da ficção, cabe a tarefa de enunciar o discurso, como protagonista da comunicação narrativa ${ }^{19}$ (LOPES; REIS, 1988, p. 61).

\section{METHODOLOGICAL STRATEGIES}

In order to observe the incidence of interpretative and feature story texts in the newspapers analyzed, it was necessary to develop a table, so as to systematize the findings quantitatively and, later, analyze them qualitatively. The model below was applied to all the newspaper pages, except for the classifieds.

Table 1 Model used in the analysis

\begin{tabular}{|c|c|c|c|}
\hline & & Gazeta do Sul & Zero Hora \\
\hline \multicolumn{4}{|c|}{ Edition or Section } \\
\hline \multicolumn{4}{|c|}{ Editorial office and page } \\
\hline \multicolumn{4}{|c|}{ Position on the page } \\
\hline \multirow{5}{*}{ 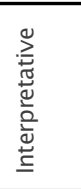 } & Report & & \\
\hline & Dossier & & \\
\hline & Profile & & \\
\hline & Opinion poll & & \\
\hline & \begin{tabular}{|l} 
Chronology \\
\end{tabular} & & \\
\hline \multirow{2}{*}{ 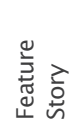 } & Story of human interest & & \\
\hline & Colorful story & & \\
\hline
\end{tabular}

Source: elaborated by the authors. 
The first three analytical categories correspond to the organization of texts on the pages of the newspapers Gazeta do Sul and Zero Hora.

Edition or section: separates texts according to the section of the newspaper where they were published. The word "section" encompasses booklets containing special content that differs from the rest of the newspaper, with different periodicity; they are published separately and included in the newspaper edition on specific days.

Editorial office and page: shows the location of texts in the newspaper and sections.

Position on the page: texts are classified according to the position on the page: top, center or bottom - footer.

The other categories consider more specifically the incidence of feature story and interpretative texts.

Interpretative journalism: the text allows for not only the author's stance but also a contextualized interpretation / explanation of the content by whoever accesses it, based on the level of newsworthiness of happenings and freedom of style.

Feature Story: these are texts that '(...) fincados no real, procuram dar uma aparência romanesca aos fatos e personagens captados pelo repórter ${ }^{20}$ ' (MARQUES DE MELO, 1985, p. 22). Feature story texts draw on literary expression forms (flashbacks, dialogues, psychological deepening, etc.).

Five genres compose the category of interpretative journalism:

Dossier: a mosaic that aims to facilitate comprehension of events. It presents facts condensed into boxes and illustrated with graphs, maps or table, whilst seeking to complement the main narratives of an edition.

Profile: synthetic biographical report that identifies the agents of the facts.

Opinion poll: randomly chosen points of view or reports from members of the public.

Chronology: reconstitution of events that can follow different time periods (secular, annual, weekly, hourly). It aims to rebuild the flow of events, allowing the reader to comprehend it clearly.

Report: a way of deepening information by contextualizing facts in time and space. 
Importantly, the genre 'report', rather than the classification proposed by Marques de Melo (2010), was opted for within the interpretative category, since interpretation also represents a way to deepen information and make it more interesting. Therefore, the following genres compose the category of interpretative journalism: dossier, profile, opinion poll, chronology and report.

Nevertheless, José Marques de Melo's classification (2010) is applied with respect to feature story journalism genres, namely the:

Story of human interest: a narrative that enlightens specific characteristics of the agents of the facts. By using literary resources, it shows unexpected aspects of anonymous people or humanizing characteristics of public people.

Colorful story: a report of pictorial nature that uses tones and hues to reconstitute reported facts. It provokes an impressionist reading that addresses the essence of happenings, identifying enriching details that may illuminate main or secondary agents' actions.

\section{QUANTIFYING DATA}

The analysis of Gazeta do Sul and Zero Hora pages showed that feature story and interpretative categories appeared frequently in the objects analyzed. There were 72 instances of texts from the five genres of interpretative categories in Gazeta do Sul. Reports prevailed (34), followed by profiles (16) and dossiers (14). There were seven cases of chronology and one opinion poll, as displayed in the table below:

Table 2 Incidence of interpretative and feature story categories in Gazeta do Sul

\begin{tabular}{|c|c|c|c|c|c|c|}
\hline \multicolumn{7}{|c|}{ Gazeta do Sul } \\
\hline Report & Dossier & Profile & Opinion poll & Chronology & Stories of human interest & Colorful stories \\
34 & 14 & 16 & 1 & 7 & 8 & 1 \\
\hline
\end{tabular}

Source: elaborated by the authors

In Zero Hora, the incidence was twice as high (145), again demonstrating the prevalence of reports (69). Dossiers were next (52), followed by profiles (21), opinion polls (2) and chronology (1). In both publications combined, there were thus 217 interpretative and feature story texts found in the samples. 
Table 3 Incidence of interpretative and feature story categories in Zero Hora

\begin{tabular}{|c|c|c|c|c|c|c|}
\hline \multicolumn{7}{|c|}{ Jornal Zero Hora } \\
\hline $\begin{array}{c}\text { Report } \\
69\end{array}$ & Dossier & Profile & Opinion poll & Chronology & Stories of human interest & Colorful stories \\
11 & 21 & 2 & 1 & 19 & 19 \\
\hline
\end{tabular}

This concerns the profile entitled 'Disputa ao Piratini: Pedro

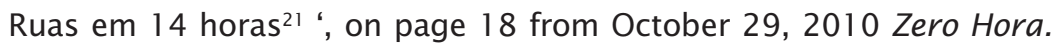
The text by Fernanda Zaffari, was illustrated with ten photographs by Diego Vara; it was part of a series that focused on what was called, in the supporting line, 'the more personal and less political side of political characters'. This is what appeared in the first paragraph, where, rather than a lead, there was a description of Pedro Ruas getting dressed.

O candidato do PSOL ao governo do Estado, Pedro Ruas, 54 anos, é marcante quando o assunto é estilo: usa óculos de armação larga e preta, os da hora são Dolce \& Gabbana, e veste sempre suspensórios.

- Uso há muito tempo, desde criança - contou logo cedo, no café da manhã no comitê do PSOL ${ }^{22}$ (ZAFFARI, 2010, p.18).

Significantly, the description of apparently irrelevant details, such as the brand and style of eyeglasses or suspender, where there should be a lead (if it were news), lends new features to Pedro Ruas. Using narrative, the text turns him into a character with concerns other than politics. It is a narrator that informs of the matter, who not only narrates but also witnesses what occurs at that moment in the character's routine; this is revealed when it is discovered that such information was obtained 'early in the morning, at breakfast'.

A similar trend featured in the text ' $O$ mão de Tesouras espalha discípulos ${ }^{23}$ 'by reporter Nilson Mariano, with photographs from Arivaldo Chaves, published on page 38 of Zero Hora, on September 25, 2010. In contrast, however, the socially relevant happening, which usually captures the attention of newspapers due to newsworthiness criteria, is not present. The story is of a character that has the ability to prune shrubs, who is compared fleetingly to the character of the movie Edward Scissorhands, played by Johnny Depp. In terms of genre, this is a human interest feature story, as it highlights a specific trait of farmer Fredolino Serliro Schmidt, aged 74: his ability to turn shrubs into artistic shapes.

The narrator is creative in describing the character's life: 
Fredolino também escapa à regra. Era agricultor, plantava milho e soja, tratava porcos e galinhas. A topiaria nasceu por acaso: em 1988, ao deixar o Coral Carlos Gomes, onde ensaiara como tenor, ouviu um comentário instigante de Ivar Roessler, prefeito de Vitor Graeff mais de uma vez:

- Bah, mas que pena não se ter um jardineiro na cidade para fazer uns desenhos nos ciprestes da praça. - disse Roessler.

- Mas dá para fazer isso. - respondeu Fredolino.

E as mãos calejadas de quem cortava lenha a machado passaram a se devotar à escultura ${ }^{24}$ (MARIANO, 2010, p. 38).

Whether it is due to the use of unusual words, such as topiarythe art of pruning gardens - or the presence of interjections, dialogues and recollections, the source once again becomes a character in the words of the author/narrator: he observes and knows everything, yet he does not participate directly in the scene.

The text 'Travessia sileNciosa'25 by Elemir Polese, with photographs from Janaína Zílio, was published in the September 4 -5, 2010 joint edition; it reveals a feature story narrative in Gazeta do Sul. The text narrates the story of a boy called Felipe, who, because of a life of poverty, cannot be a child. The following is the opening of the text:

\begin{abstract}
Geralmente, há vidas no caminho. E quando elas não estão no caminho, algo pode estar errado. E algo está errado na vida de Felipe. Felipe logo completará nove anos, mas parece ter cinco. E ainda não vai para a escola como seus amiguinhos da vila onde mora. Em uma das manhãs, o Felipe miudinho se agiganta e questiona seu pai: 'Pai, quando é que vou pra escola?' 'Ano que vem, meu filho, ano que vem.' 'Mas porque não agora, pai?' 'A melhor escola é a da vida, meu filho, teu pai também aprendeu assim²6 '(POLESE, 2010, p. 48).
\end{abstract}

This does not point to a clear need to inform; yet the text provides Felipe's physical and emotional description. In addition to being fictionalized, he does not have a last name. Once again, the protagonist is a character rather than a source. Equally, the narrator is demiurgic, and describes from a distance what happens with respect to the father, son and poverty.

In the same Gazeta do Sul edition ${ }^{27}$, on pages 22 and 23, there is an interpretative text signed by reporter Nero Setúbal, with photographs from Janaína Zílio. The report is about 'aging', based on a survey on aging among the population, and discusses events as they take place -communication media campaigns in Santa Cruz do Sul, measures against aging, etc. - but it describes a more comprehensive reality. The text contains remarkable stylized language, with metaphors and time reminiscences. For instance: 
Deixados de lado pelo próprio sangue, os internos ainda convivem com o fato de saber que por lá, mais do que em qualquer outro lugar, é comum relações serem rompidas do dia para a noite sem aviso prévio. 'Vez que outra a gente vê um colega partindo em um carro de funerária. Tem parente que não aparece nem para os atos fúnebres. É o pior. Mas a vida segue', diz seu Claudionor com a experiência de quem sabe que a estrada é tortuosa e precisa ser encarada de frente. Independente de como será o fim²8 (SETÚBAL, 2010, p. 22-23).

Both the location (section or newspaper body text) and regularity of feature stories and interpretative texts stand out. In the case of Gazeta do Sul, there are 23 texts of interpretative and feature story categories in the sections, and 50 in newspaper body text. Similarly, in Zero Hora, there are 46 texts of feature story and interpretative nature in the sections and 129 in newspaper body text. Thus, less than half the texts are located in specific sections, whether it be in Gazeta do Sul or Zero Hora.

The tables below allow demonstrate this situation:

Table 4 Location of the texts in Gazeta do Sul

\begin{tabular}{|l|c|c|}
\hline \multicolumn{3}{|c|}{ Jornal Gazeta do Sul } \\
\hline Location & Interpretative & Feature story \\
\hline Sections & 19 & 4 \\
\hline $\begin{array}{l}\text { Newspaper body } \\
\text { text }\end{array}$ & 53 & 5 \\
\hline
\end{tabular}

Source: elaborated by the authors.

Table 5 Location of the texts in Zero Hora

\begin{tabular}{|l|c|c|}
\hline \multicolumn{3}{|c|}{ Zero Hora } \\
\hline Location & Interpretative & Feature story \\
\hline Sections & 27 & 19 \\
\hline $\begin{array}{l}\text { Newspaper body } \\
\text { text }\end{array}$ & 118 & 11 \\
\hline
\end{tabular}

Source: elaborated by the authors.

Regarding regularity, defying common sense, the sample suggests that texts of interpretative and feature story categories are not mostly found scattered throughout Sunday and Saturday editions (Zero Hora) or weekend editions (Gazeta do Sul). Instead, they are released on days when people have more time for reading, and are common on weekdays, including Mondays, as evidenced in the tables below: 
Table 6 Frequency of interpretative and feature story categories in Zero Hora

\begin{tabular}{|l|c|c|}
\hline Jornal Zero Hora & Interpretative & Feature Story \\
\hline Monday & 17 & 2 \\
\hline Tuesday & 22 & 5 \\
\hline Wednesday & 21 & 7 \\
\hline Thursday & 15 & 2 \\
\hline Friday & 14 & 1 \\
\hline Saturday & 17 & 8 \\
\hline Sunday & 39 & 5 \\
\hline
\end{tabular}

Source: elaborated by the authors.

Table 7 Frequency of interpretative and feature story categories in Gazeta do Sul

\begin{tabular}{|l|c|c|}
\hline Jornal Zero Hora & Interpretative & Feature Story \\
\hline Monday & 5 & 0 \\
\hline Tuesday & 12 & 2 \\
\hline Wednesday & 19 & 1 \\
\hline Thursday & 12 & 0 \\
\hline Friday & 9 & 0 \\
\hline Saturday/Sunday* & 18 & 6 \\
\hline
\end{tabular}

* Joint edition

Source: elaborated by the authors.

Taking into account the proportions of each newspaper, the tables show that in Zero Hora, feature story texts are present every day. The highest incidence is on Saturdays, due to the publication of the Culture Section, followed by Wednesdays (7) and Tuesdays (8). As for interpretative texts, the highest incidence in Zero Hora is on Sundays (39), Tuesdays (22) and Mondays (21).

The table that presents Gazeta do Suls figures also shows the hegemony of interpretative texts, especially on Wednesdays (19), Saturdays/ Sundays (18) and Tuesdays and Thursdays (12). The feature story category appears mostly on weekends (6), Tuesdays (2) and Wednesdays (1). On Mondays and Fridays, however, there are no such texts, perhaps because on Tuesdays and Fridays, resources are devoted to the weekend edition, while on Sundays there is only one reporter to cover the news.

In order to point out the variations of physical space occupied by feature stories and interpretative texts, given that a priori they are not concise texts, the space was divided into three groups: half a page, one page, more than one page, as displayed in Tables 8 and 9. 
Table 8 Length of the texts in Gazeta do Sul

\begin{tabular}{|l|l|l|}
\hline \multicolumn{3}{|c|}{ Gazeta do Sul } \\
\hline Length & Interpretative & Feature Story \\
\hline Half a Page & 29 & 4 \\
\hline One Page & 36 & 4 \\
\hline More than one page & 7 & 1 \\
\hline
\end{tabular}

Source: elaborated by the authors

Quantification suggests that both in Gazeta do Sul and Zero Hora, the average space dedicated to this sort of text is one page, as there are 40 cases in Gazeta do Sul and 86 in Zero Hora. The latter differs from the former in using more than one page for this kind of text: 58 texts versus 8 in Gazeta do Sul. Again, figures are similar as regards using half a page: 33 cases in Gazeta do Sul and 31 in Zero Hora.

\section{INTERPRETATIVE CONSIDERATIONS}

Although the survey is at the data interpretation stage, based on the information collected ${ }^{29}$, it is nonetheless possible to draw some interpretative considerations. The figures in Tables 2 and 3 , concerning the incidence of interpretative and feature story categories both in Gazeta do Sul and Zero Hora, suggest that, regarding the interpretative category, reports represent the most common genre in both newspapers, followed by dossiers, in the case of Zero Hora (52) and profiles in the case of Gazeta do Sul (16). In Gazeta, dossiers are third (14), while profiles are third in Zero Hora (no.). A possible interpretation of these data considers that during the period of analysis, the newspapers sought to provide readers with more contextualized information, rather than just news, regarding both happenings (such as reports and dossiers) and characters that stood out for any reason (as seen in profiles).

Zero Hora seemed particularly dedicated to feature story texts. There are 19 human interest stories and 11 colorful stories. In Gazeta do Sul, the figures show lower numbers: 8 human interest stories and only one colorful story. Understanding the significance of these numbers demands observing possible organizational glitches, as the publications have different newsrooms (Zero Hora encompasses an entire state whereas Gazeta do Sul is regional), and therefore different resolution capacities. 
Tables 6 and 7, which treat the frequency of interpretative and feature story categories in Zero Hora and Gazeta do Sul, reinforce such ideas. On the one hand, in Zero Hora, feature story texts appear mostly on Saturdays (8), and on Mondays the least (2), suggesting a continuous production; on the other hand, in Gazeta do Sul, this type of text does not feature on three days of the week: Mondays, Thursdays and Fridays. In the joint weekend edition, there are 6 such texts, which implies that on days when interpretative and feature story texts are absent, they are actually being written.

As Tables 4 and 5 demonstrate, in both newspapers, interpretative and feature story texts appear in the sections and newspaper body texts, suggesting a constant concern for establishing differences, using specific language where news prevails. The samples show clearly reporters' and editors' concerns regarding the stylization of contents such as "general", "politics" and "economy", thus establishing differences in comparison with other informative media and texts from the newspaper itself.

The issue of the amount of space used in both newspapers highlights an important point: although it is stylized texts that are under discussion, which therefore might occupy more space on pages, there is a prevalence of one-page texts in both Zero Hora and Gazeta do Sul; with 86 one-page texts in Zero Hora and 40 in Gazeta do Sul. The next most common format is two-page texts, in Zero Hora, and texts of half a page in the case of Gazeta do Sul.

What does this signify? Again, the logic of division of space for texts corresponds to the availability of pages in each edition; in the case of newspapers, it is strictly connected to the amount of ads, holidays and weekdays (there are fewer texts at the beginning of the week but more by the end of the week). The latter are therefore marketing matters. Hence, even if space is limited, newspapers are concerned about establishing differences that distinguish them internally and from competitors, leaning on texts to do so and becoming a need for the reader.

The data suggest that a change is underway in journalism and that it may require a novel approach to be understood properly. The journalistic categories and genres, which have been utilized here in accordance with Jose Marques de Melo (2010), illustrate the initial claim. As explained, the complex scenario required that Marques de Melo himself review what he had advanced several years previously, through adding new categories into his analytical framework, thus indicating that they also occupy a distinguished place in the analysis.

Therefore, perhaps they act mainly as "bioindicators" of deeper 
layers of meaning, or even signs of a larger textual and argumentative diversity than discursive compartmentalization. Similarly, the research group "Journalism and literature: complexified narratives" (part of the Post-Graduation Program in Languages and Literature and the Communication Division at UNISC) noticed that, from a mediatization perspective, the journalistic categories and genres act as indicators of deeper layers of signification than textual compartmentalization mechanisms (SOSTER et al., 2013). Such observations involve recognizing that the analytical scenario is changing.

The data also suggest that the journalistic devices, while utilizing textual strategies derived from other fields of knowledge, including literature, as discussed in this paper, and establishing differences in relation to the other vehicles, also generate new meanings. They thus affect the structures, processes and agents involved in their operational procedures, being equally transformed by this movement, complexifying themselves again. Without delving further at this stage, drawing on phenomenological analytical perspectives, it is clearly essential to understand what these meanings represent, in order to advance future analyses.

\section{NOTES}

1 Paper originally presented at the 34th Brazilian Congress of Communication Sciences, sponsored by the Brazilian Society of Interdisciplinary Studies Communication (Intercom) from 2 to 6 September 2011 in Recife, Pernambuco, and later updated, without changing its essence.

2 The concept of autonomy, when applied to systems, does not point to independence from the surroundings, but to a self-referential closure: the surroundings may limit or broaden the ambit of the system's operational possibilities, but they do not annul the fact that the operations are produced and connected only in and by the system (Baraldo, Corsi, Esposito 1996:36-37).

3 'In all sorts of self-reference, there is a closed circularity, which does not deny the existence of the surroundings; this is the presupposition for the system's selections'.

4 Irritation is understood here as the disturbance the environment 
causes in the system (it is not possible to consider the system outwith the environment), which is regarded as information, and is processed as such.

5 This topic has been studied since 2010 by the members of the Research Project 'A narrativa jornalística e sua intersecção com a literatura', part of the Programa de Pós Graduação em Letras of UNISC. The group is coordinated by Professor Demétrio de Azeredo Soster and Professor Fabiana Piccinin; members include postgraduate student Vanessa Kanneberg and volunteers Pedro Piccoli Carcia, Joel Haas and Marília Nascimento. Using empirical data, this article deepens and broadens the discussions led by the group internally and externally, for example, in the paper 'Jornalismo diversional e interpretativo: diferenças que estabelecem diferenças', presented at the GT Gêneros Jornalísticos of the 33rd Congresso Brasileiro de Ciências da Comunicação de 2010, in Caxias do Sul, Brazil.

6 The distinction between category and genre, as well as the as acceptance of either one or the other as classifications in journalistic reports, is debatable and complex and has been the focal point of discussion for a long time. Social sciences, for example, refer to 'category' as a group of people with similar behavioral characteristics, allowing them to be identified as belonging to a certain group (Johnson 1997). The concept of genre, from this perspective, refers to individual characteristics of group members. This study adopts the stance of Marques de Melo (1985), who argues that 'category' is a concept of discursive nature that defines, in several ways and on various levels, domains of knowledge and action. Genres, in turn, concern the modes of expression employed in these domains. The defining trait of genre is style: the way one writes. Therefore, a 'journalistic category' is informative, interpretative, feature story, opinionated, etc; while genre concerns variations in a given style (for example, editorial genre in opinionated category).

7 Zero Hora from Porto Alegre is the sixth largest-circulation newspaper in Brazil and the largest in Rio Grande do Sul, with over 185,000 copies per day. Gazeta do Sul circulates in 36 cities in the centre of Rio Grande do Sul, with approximately 15,000 copies per day.

8 In Portuguese, the term "jornalismo diversional" (diversional journalism) best defines this genre of journalism, as it encompasses subcategories such as "human interest story" and "colorful story", drawing on José Marques de Mello's perspective. However, "feature story" has been adopted here, as a synonym for "human interest 
piece", since the term "jornalismo diversional" has no equivalent in English. In addition, the term "feature story" embodies part of its meaning, given that it refers to: a) style (narrative), which is inherent to "diversional"; and, as has been mentioned, b) one of the genres that composes the category known as "diversional".

9 Mediatized journalism is that whose devices are more than vectors of mediatization; they are obtained by processuality and mediatize. Mediatization is the creation of new environments based on society's deep technological, social, and discursive immersion.

10 Self-reference is observable when discursive operations of journalistic devices turn to their own text, by evincing characteristics and explaining operations (usually using supporting verbs), and then establishing new bonds, for instance, by using expressions such as: 'According to our investigation'... The co-reference is established as operations of media- communication systems turn to their own systems, and the devices that compose them initiate increasingly frequent dialogues with their counterparts. Thus, two knots of the system unite, communication being the conducting wire between them. Decentralization is related to the fact that, from a systemic perspective, journalistic devices become knots and connections in a web of hegemonically institutional places (SOSTER, 2009).

11 The media-communication system in this article is termed 'journalistic' and is established as such when print newspapers and magazines, radio, television broadcasters, online newspapers, journalistic websites, blogs and microblogs of journalistic nature gather on the internet.

12 'The devices that represent journalism are merged within web knots and connections by shaping the media-communication system and establishing operations in informative flows of pointedly selfreferential nature, complexifying a 300 year-old evolutional logic'.

13 Web as a synonym for World Wide Web, or WWW, or the Internet.

14 Flows, in Castells' opinion (2003) represent the expression of a process that controls economic, political and symbolic life. 'O espaço de fluxos é a organização material das práticas sociais de tempo compartilhado que funcionam por meio de fluxo' (CASTELLS, 2003, p. 501). ['The flow space is the material organization of social practices of shared time that work based on flows'].

15 'As complex phenomena, changes in one or more subsystems alter and condition the totality. Thus, it is not surprising that the 
digitalization of media and production means, the spirit of these times and the economic and political arrangements, demand updates in research and their own explicative academic passwords'.

16 In this bias, journalistic texts are divided into reports and versions of these reports. The first group encompasses categories such as informative, feature story and interpretative; the second includes opinionated texts.

17 Happening is used as a synonym for something unexpected, new, related to journalism at its different levels (mostly production, emission and reception). For further reading on the concept of happening, consult the book: Jornalismo e acontecimento: mapeamentos críticos (INSULAR, 2010).

18 'A difference that leads to a change in the system itself; because it happens, it transforms: (the recipient) reads that smoking, alcohol, butter, frozen meat put life at risk and becomes (as one who knows it and can consider it) another, whether one believes the information or not. No matter how one decides, communication fixes a position in the recipient. Afterwards, the acceptance, the rejection or the immediate reaction to the information do not matter. What is fundamental is that the information makes a difference: a difference that makes a difference'.

19 'The definition of the concept of narrator must start from the unequivocal distinction regarding the concept of author, an entity commonly confused with the narrator but which is really endued with a different functional and ontological status. While the author corresponds to a real empirical entity, the narrator is fundamentally understood as the textual author, a fictional entity that, in the fictional scenery, has the task of enunciating the discourse, as the leading figure in the narrative communication'.

20 '(They) are attached to reality and aim to draw facts and characters captured by the reporter with novel-like features'.

21 Zero Hora, year 47, No. 16.462, second edition, 29 October 2010, pp. 18.

22 'PSOL candidate for governor Pedro Ruas, 54, outstands when the matter is style: he wears thick black eyeglasses, the current pair are Dolce \& Gabbana, and he always wears a suspender -l've been wearing it for a long time, since I was a child - he said early in the morning at the PSOL comity breakfast'. 
23 Zero Hora, year 47, No. 16458, second edition, 25 September 2010 , pp 38.

24 'Fredolino also escapes the rule: he was a farmer, used to plant corn and soy, and raise pigs and chicken. Topiary was not in his plans: in 1998, when he left Carlos Gomes Coral, where he rehearsed as a tenor, he repetitively heard instigating comments from Mayor Ivar Roessler:

-Oh, it is such a pity there is no gardener in town to prune some shapes in the shrubs of our square.- Roessler said.

- But we can do it. - Fredolino answered.

And the calloused hands of someone who was used to chopping wood with an axe started dedicating themselves to topiary'.

25 Gazeta do Sul, year 66, No. 190, editions 4 and 5, September 2010, pp 48.

26 'There are usually lives along the way. And when they are not along the way, something must be wrong. And there is something wrong in Felipe's life. Felipe will soon turn nine, but he looks five. And he does not go to school with his friends from the slum where he lives. On one morning, little Felipe grows big and asks his father: "Dad, when am I going to school?" "Next year, my son, next year". "But why not now?" "The best school is life, my son, your father learned this way too"'.

27 Gazeta do Sul, year 66, No. 190, editions 4 and 5 September 4-5 2010, pp 22-23.

28 'Abandoned by their own blood, the inmates have to live with the knowledge that there, more than anywhere else, it is common for relationships to be interrupted overnight, without notice. "Now and then we see a roommate leaving in a hearse. There are families that do not even bother to show up at the funeral. And there is worse. But life goes on", says Mr. Claudionor, with the experience of someone who knows the road is tortuous and must be faced, regardless of what it will be like in the end'.

29 The next stage of research intends to conduct interviews with editors and reporters in order to verify the data collected in the quantitative survey. 
REFERENCES

BARALDI, Cláudio; CORSI, Giancarlo; ESPOSITO, Elena (Org.). Glossário sobre la teoria social de Niklas Luhmann. México: Anthropos, 1996.

BELTRÃO, Luiz. Jornalismo opinativo. Porto Alegre: Sulina, Ari, 1980.

CASTELLS, Manuel. A sociedade em rede. São Paulo: Paz e Terra, 2003. (A Era da Informação: economia, sociedade e cultura, 1);

CHAPARRO, Manuel Carlos. Sotaques d'aquém e d'além mar: travessias para uma nova teoria dos gêneros jornalísticos. São Paulo: Summus Editorial, 2008.

MARCONDES FILHO, Ciro (ORG.) Dicionário de Comunicação. São Paulo: Paulus, 2009.

JONHSON, Alan. Dicionário de Sociologia - Guia Prático da Linguagem Sociológica. Rio de Janeiro: Jorge Zahar Editor, 1997.

LOPES, Ana Cristina M.; REIS, Carlos. (Org.) Dicionário de teoria narrativa. São Paulo: Ática, 1988.

LUHMANN, Niklas. Introdução à teoria dos sistemas. São Paulo: Vozes, 2009.

MARIANO, Nilson. O mão de Tesouras espalha discípulos. Zero Hora, ano $47, \mathrm{n}^{\circ} 16.458,2$. ed., 25 de setembro de 2010 .

MARQUES DE MELO, José. Gêneros jornalísticos: conhecimento brasileiro. In: MARQUES DE MELO, José; ASSIS, Francisco de. Gêneros jornalísticos no Brasil. São Bernardo do Campo: Universidade Metodista de São Paulo, 2010.

MARQUES DE MELO, José. A opinião no jornalismo brasileiro. Petrópolis: Vozes, 1985.

POLESE, Elemir. A travessia silenciosa. Gazeta do Sul, ano 66, n 190 , 4-5 de setembro de 2010.

PICCININ, Fabiana; SOSTER, Demétrio de Azeredo. Jornalismo diversional e jornalismo interpretativo: diferenças que estabelecem diferenças. In: XXXIII Congresso Brasileiro de Ciências da Comunicação, 33., 2010, Caxias do Sul. Anais...Caxias do Sul, 2010.

PRIMO, Alex. Prefácio. In: FIRMINO DA SILVA, Fernando; SOSTER, Demétrio de Azeredo (Org.). Metamorfoses jornalísticas 2: a reconfiguração da forma. Santa Cruz do Sul: Edunisc, 2009.

SEIXAS, Lia. Redefinindo os gêneros jornalísticos: proposta de novos critérios de classificação. Covilhã: LabCom, 2009. Available at: http:// 
www.livroslabcom.ubi.pt/pdfs/seixas-classificacao-2009.pdf. Accessed on: 5 de fevereiro de 2009.

SETÚBAL, Nero. Uma população que não pára de crescer. Gazeta do Sul, ano $66, \mathrm{n}^{\circ} 190,4-5$ de setembro de 2010.

SOSTER, Demétrio de Azeredo. Dialogia e atorização: características do jornalismo midiatizado. In: $10^{\circ}$ Encontro Nacional dos Pesquisadores de Jornalismo, 10., 2013, Brasília. Anais... Brasília, 2013.

SOSTER, Demétrio de Azeredo et al. O que dizem os gêneros na narrativa jornalística não-biográfica de Fernando de Morais. XXXVI Congresso Brasileiro de Ciências da Comunicação, 36., 2013, Manaus. Anais..., Manaus, 2013.

SOSTER, Demétrio de Azeredo. O jornalismo em novos territórios conceituais: internet, midiatização e a reconfiguração dos sentidos midiáticos. São Leopoldo: Unisinos, 2009. Tese (Doutorado em Comunicação). São Leopoldo: Programa de Pós-graduação em Comunicação, Universidade do Vale do Rio dos Sinos, 2009.

SOSTER, Demétrio de Azeredo. Auto-referência e co-referência nas páginas do jornal Folha de S.Paulo. In: $7^{\circ}$ Encontro Nacional dos Pesquisadores de Jornalismo, 7., 2009, São Paulo. Anais... São Paulo, 2009-a

SOSTER, Demétrio de Azeredo. Midiatização, a terceira descontinuidade do jornalismo. In: $6^{\circ}$ Encontro Nacional dos Pesquisadores de Jornalismo, 6., 2008, São Bernardo do Campo. Anais... São Bernardo do Campo, 2008.

SOSTER, Demétrio de Azeredo. O jornalismo para além de suas fronteiras conceituais. In: $5^{\circ}$ Encontro Nacional dos Pesquisadores de Jornalismo, 5., 2007, Aracaju. Anais... Aracaju, 2007.

ZAFFARI, Fernanda. Disputa ao Piratini: Pedro Ruas em 14 horas. Zero Hora, ano 47, n. 16.462, 2. ed., 29 de outubro de 2010. 
Demétrio de Azeredo Soster Head of Department of Social Communication at UNISC (Universidade de Santa Cruz do Sul). Professor on The Postgraduate Program for Language and Literature and the Undergraduate Social Comunication Program (UNISC).E-mail: dsoster@ uol.com.br

Fabiana Quatrin Piccinin Coordinator of the Postgraduate (research) program at UNISC (Universidade de Santa Cruz do Sul). Professor on The Postgraduate Program for Language and Literature and the Undergraduate Social Comunication Program (UNISC). E-mail: fabianapiccinin@hotmail.com 